
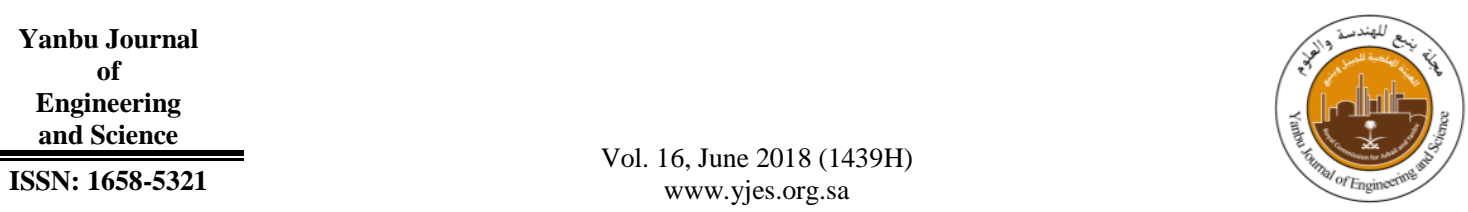

\title{
HEADSPACE GAS CHROMATOGRAPHY FOR THE DETERMINATION OF RESIDUAL SOLVENTS IN METFORMIN HYDROCHLORIDE AND HYDROCHLOROTHIAZIDE
}

\author{
SK Manirul Haque ${ }^{1}$, Yunusa Umar ${ }^{1 *}$, Omar Ashwaq.H.H ${ }^{1}$, Sree Kumar P.A ${ }^{1}$, Prem Shanker ${ }^{2}$ \\ ${ }^{1}$ Department of Chemical and Process Engineering Technology, Jubail Industrial College, Royal Commission of Jubail, \\ P.O.Box 10099, Zip Code: 31961, Kingdom of Saudi Arabia. \\ ${ }^{2}$ Department of Quality Control, Blue Circle Organics Private Limited, Ambernath, Maharashtra, India. \\ E-mail: umar_y@jic.edu.sa
}

\begin{abstract}
An accurate analytical method was developed using headspace gas chromatography for the determination of residual solvents in metformin hydrochloride and hydrochlorothiazide. The residual solvent was studied with the help of gas chromatography (Shimadzu 2014 model) combined with Teledyne Tekmar headspace and GC solution software. The residual solvents were separated using DB-WAX column 30-meter-long, $0.32 \mathrm{~mm}$ internal diameter for metformin hydrochloride and BP624 column 30-meter-long, $0.53 \mathrm{~mm}$ internal diameter for hydrochlorothiazide. The limit of detection and limit of quantitation of dimethylacetamide, methanol and benzene were $17.00,10.93,0.18$ and $51.92,33.13,0.57 \mathrm{ppm}$ respectively for metformin hydrochloride and in case of hydrochlorothiazide, the values were $3.40 \&$ $1.30 \mathrm{ppm}$ and $10.15 \& 4.00 \mathrm{ppm}$ for methanol and methyl isobutyl ketone respectively. The method was validated according to international conference on harmonization guideline in terms of specificity, linearity, precision, accuracy and robustness.
\end{abstract}

Keywords: Metformin hydrochloride, Hydrochlorothiazide, Residual Solvents, Dimethylacetamide,Methanol, Benzene, MIBK, HSGC, Validation.

\section{INTRODUCTION}

Metformin hydrochloride (MH) in Figure 1 belongs to the biguanide class, it is chemically known as 1,1-dimethyl biguanide monohydrochloride and is specific for the treatment of diabetes [1-2]. $\mathrm{MH}$ controls gluconeogenesis process in the liver during the production of glucose, it also reduces absorption of glucose in the intestines and improves insulin sensitivity by increasing peripheral glucose uptake and utilization. Hydrochlorothiazide (HCTZ) in Figure 1 is an antihypertensive drug and a thiazide type diuretic prescribed for the last 5 decades as a medicine to treat high blood pressure [3]. There are many other drugs available in the market but HCTZ have the ability to minimize cardiovascular attack, and efficacy due to its pharmacokinetic property. 2H-1,2,4Benzothiadiazine-7-sulfonamide,6-

chloro3,4-dihydro-,1,1-dioxide is the chemical name of HCTZ, and is mainly used for the treatment of hypertension, diabetes and kidney stones. The mechanism of drug synthesis consists of many routes and each one requires an intermediate as well as a different solvent. It is very important to remove all impurities from the drug, but the results show that some are still present as volatile 
organic impurities (residual solvent), this is because the traces of solvent is not possible to remove completely. These solvents are toxic in nature, so pharmaceutical industries have concern over the presence of residual solvent in the final product. The international conference on harmonization ( $\mathrm{ICH})$ has limited the amount of residual solvent in their guidelines and has classified it as I, II and III according to the toxicity level and environmental hazard [4]. In our opinion the best technique to determine the residual solvent in bulk as well as in formulation is gas chromatography combined with static headspace (HSGC), as it has the ability to separate solvents with great accuracy and with very low detection limit [5-11]. The supplier claims dimethylacetamide, methanol, benzene for metformin hydrochloride and methanol, methyl isobutyl ketone for hydrochlorothiazide are present in the final product. To the best of our knowledge there is no validated HSGC method available for the analysis of residual solvents in $\mathrm{MH}$ and HCTZ. Therefore, a precise HSGC method is essential for the determination of residual solvent present in the above mentioned drugs. In the present study, static headspace gas chromatography methods with flame ionization detector are developed for the determination of residual solvent. The methods are then validated according to ICH guidelines. The developed method is quiet simple and precise for the determination of residual solvent in bulk and it can be used to quantify the same in the pharmaceutical formulations.

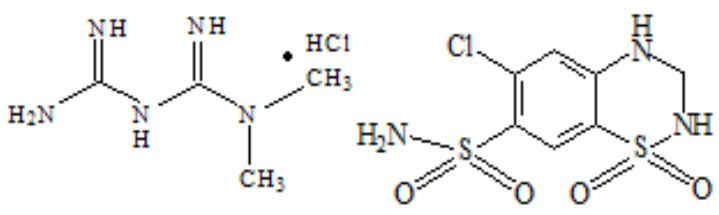

Fig. 1. Structure of metformin hydrochloride and hydrochlorothiazide.

\section{EXPERIMENTAL}

\subsection{CHROMATOGRAPHIC CONDITIONS}

The analytical methods were developed with the help of Shimadzu 2014 gas chromatography (Japan) in combination with headspace auto sampler (USA). Flame ionization detector (FID) is suitable for the analysis and nitrogen was used as carrier gas for the study. GC was connected with computer and controlled by Total Chrome Navigator software. All experiments were performed using a DBWAX column with 30-meter-length and $0.32 \mathrm{~mm}$ internal diameter for metformin hydrochloride (MH) and a BP624 column with 30 -meter-length and $0.53 \mathrm{~mm}$ internal diameter for hydrochlorothiazide (HCTZ). Below are the parameters (Table 1) that were followed throughout the analysis for the quantification of residual solvents in $\mathrm{MH}$ and HCTZ.

\subsection{DRUGS AND CHEMICALS}

Dimethylacetamide (GC Headspace grade), methanol (HPLC grade), methyl isobutyl ketone (HPLC grade) from Thermo Fisher Scientific Private Limited, India and benzene (HPLC grade), dimethyl sulphoxide (HPLC grade) and drugs metformin, hydrochlorothiazide were purchased from Sigma Aldrich, India. Drug formulations, Formin 500mg (Alembic) Glumet 500mg (Cipla) contain $\mathrm{MH}$ and Aquazide 12.5mg (Sun Pharma), Klorzide 25mg (Zydas Cadila) were obtained from local market, India.

\subsection{STANDARD SOLUTIONS AND CALIBRATION CURVE}

In order to construct standard calibration curve, stock solution of benzene (1000 ppm), dimethylacetamide (1000ppm), methanol (3000ppm) for metformin and methyl isobutyl ketone (5000ppm), methanol (3000ppm) for hydrochlorothiazide was first made. $0.1 \mathrm{~g}$ benzene, $0.1 \mathrm{~g}$ dimethylacetamide, $0.3 \mathrm{~g}$ methanol were transferred into $100 \mathrm{ml}$ 
volumetric flask and diluted up to the mark with DMSO. Another $100 \mathrm{ml}$ volumetric flask was taken with $0.3 \mathrm{~g}$ methanol and $0.5 \mathrm{~g}$ MIBK as contents and was diluted with DMSO up to the mark. The concentration of each solvent was in the range of $50-1000 \mathrm{ppm}$ after diluting with DMSO. A linear calibration plot was made between concentration (ppm) of the solvent vs peak area and a linear equation was established after calculating slope and intercept using the straight line that depends on correlation coefficient $\left(\mathrm{R}^{2}\right)$ value.

TABLE 1: PARAMETERS FOR HSGC ANALYSIS.

\begin{tabular}{|l|l|}
\hline \multicolumn{1}{|c|}{ GC } & \multicolumn{1}{|c|}{$\begin{array}{c}\text { Headspace auto } \\
\text { sampler }\end{array}$} \\
\hline$\underline{\text { Gas Flow }}$ & GC Cycle-31 min \\
$\mathrm{N}_{2}-1 \mathrm{ml} / \mathrm{min}$ & Valve Oven- $110^{\circ} \mathrm{C}$ \\
$\mathrm{H}_{2}-40 \mathrm{ml} / \mathrm{min}$ & Transfer line- $150^{\circ} \mathrm{C}$ \\
Air $-450 \mathrm{ml} / \mathrm{min}$ & Sample- $40^{\circ} \mathrm{C}$ \\
$\underline{\text { Column Temp }}$ & Equilibrium- $0.5 \mathrm{~min}$ \\
Initial-60 ${ }^{\circ} \mathrm{C}$ & Sample Equil. Time-3.0 \\
$60^{\circ} \mathrm{C}$ hold for 10 & min \\
minutes; Raised to & Pressurize time-2.00 min \\
$240^{\circ} \mathrm{C}$ at ramp & Pressurize Equil. Time- \\
$15^{\circ} / \mathrm{minute}$ and hold & 0.25 min \\
for 2 minutes; Run & \\
Time 24 minutes & \\
$\underline{\text { FID }}$ & \\
$240^{\circ} \mathrm{C}$ & \\
$\underline{\text { Injector }}$ & \\
$240^{\circ} \mathrm{C}$ & \\
\hline
\end{tabular}

\subsection{BULK DRUG AND PHARMACEUTICAL DOSAGE FORM}

Metformin hydrochloride (MH) (500mg) and hydrochlorothiazide (HCTZ) (250mg) were dissolved with $50 \mathrm{ml}$ DMSO and made up to the mark to obtain $5000 \mathrm{ppm}$ and 2500ppm respectively. The commercial products of metformin (Formin, Glumet) and hydrochlorothiazide (Aquazide, Klorzide) were accurately weighed and finely powdered separately. $500 \mathrm{mg}$ metformin and 250mg hydrochlorothiazide was dissolved with DMSO and filtered with $0.45 \mu \mathrm{m}$ Millipore filter, the solution was then diluted with DMSO to get 5000ppm and 2500ppm respectively.

\subsection{PROCEDURE}

The HS vials were of $10 \mathrm{ml}$ capacity and 2 $\mathrm{ml}$ of each solvent with different concentration are transferred in to the 10 $\mathrm{ml} \mathrm{HS}$ vials and kept at $40^{\circ} \mathrm{C}$ after tightening with the septum. The sample was collected by turbometrix and heated to produce vapor at injector temperature in the injector. The vapor of the sample was then passes through a transfer line to the gas chromatography and moved towards the column by carrier gas for separation and detection.

\section{RESULTS AND DISCUSSIONS}

A headspace gas chromatographic method was developed for the determination of residual solvent in metformin hydrochloride (dimethylacetamide, benzene, methanol) and hydrochlorothiazide (methyl isobutyl ketone, methanol). The methods were validated according ICH guidelines with respect to specificity, linearity, accuracy, precision, limit of detection, limit of quantitation, ruggedness and robustness.

\subsection{SPECIFICITY}

Stock solution is diluted to get dimethylacetamide (1000 ppm), methanol (3000 ppm), benzene ( $2 \mathrm{ppm})$ and methyl isobutyl ketone (5000 ppm) separately and each standard is prepared with same concentration as well. The standard sample of each solvent are injected separately to compare the retention time with composite sample in Figures 2 and 3. To avoid overlap and ensure better separation of peaks, two columns were used and the specificity results are provide in Table 2.

\subsection{LINEARITY AND RANGE}

The standard stock solution of benzene ( 2 ppm), dimethyl acetamide (2000ppm), methanol (1000ppm) and methyl isobutyl 
ketone (2500ppm) were prepared. All reference standard solution was prepared in triplicate by diluting stock solution with DMSO. The results were recorded and a graph was constructed between concentration (ppm) and peak area to obtain calibration curves of all residual solvents present in metformin and hydrochlorothiazide. Correlation coefficient $\left(\mathrm{R}^{2}\right)$ was calculated for all the regression equations. The linearity ranges were $0.3-1.5 \mathrm{ppm}$ for benzene, 40-250 ppm for dimethyl acetamide, 50-500ppm for methanol and 80-950ppm for methyl isobutyl ketone in Table 3.

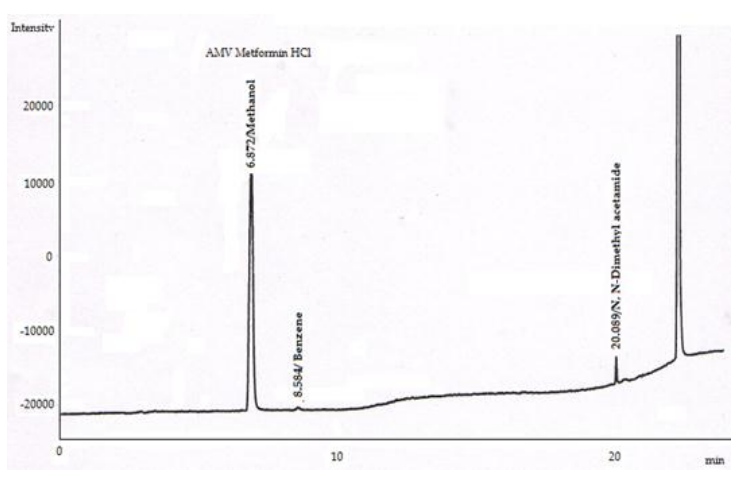

Fig. 2. Chromatogram for Metformin hydrochloride.

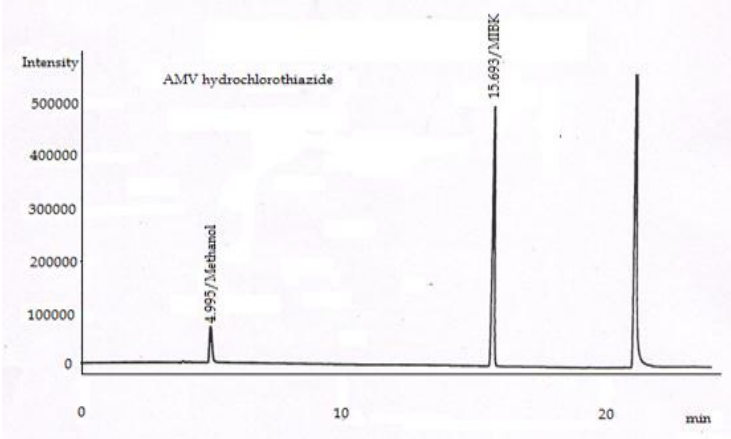

Fig. 3. Chromatogram for Hydrochlorothiazide.

\subsection{PRECISION}

The instrumentation precision was determined by applying benzene $(1.5 \mathrm{ppm})$, DMA (250ppm), methanol (500ppm) and MIBK (950ppm) with independent six replicate injections from the same vial. The percent relative standard deviation (\% RSD) for benzene, DMA, methanol and MIBK were $1.99,1.87,1.03$ and 0.76 respectively in Table 4 within the limit (15\%, ICH guidelines).

\subsection{LIMIT OF DETECTION (LOD) AND LIMIT OF QUANTITATION (LOQ)}

The LOD and LOQ were calculated using the following equations:

Limit of detection (Conc.ppm) $=\frac{3.3 \times S D}{b}$

Limit of quantification (Conc. ppm) $=\frac{10 \times S D}{b}$ where, 3.3 and 10 are factor $\mathrm{SD}=$ Standard deviation of linear regression; $b=$ Slope of linear regression. The LODs and LOQs for benzene, DMA, methanol and MIBK are provided in Table 3.

\subsection{ACCURACY}

The accuracy of standard solution of all solvents was calculated in terms of \% recovery for triplet injections of individual solvent in Table 5. The percentage recovery was calculated using the standard calibration curve or linear plot. The percentage values are within the limit (80$120 \%)$.

\subsection{ROBUSTNESS}

The robustness studies were conducted by changing the oven temperature to $5^{\circ} \mathrm{C}$ below and above the normal oven temperature. The \% RSD values for benzene, DMA, methanol and MIBK are injected triplicate separately and presented in Table 6.

\subsection{APPLICATION OF THE PROPOSED METHOD WITH PHARMACEUTICAL FORMULATIONS}

The proposed method was developed and applied to quantify the residual solvents present in pharmaceutical formulations of metformin hydrochloride (Formin, Glumet) and hydrochlorothiazide (Aquazide, Klorzide). All samples were injected three times individually but no peak of residual solvent was detected. So the results indicated solvents are not present in the pharmaceutical formulations. 
TABLE 2: SPECIFICITY RESULTS.

\begin{tabular}{|c|c|c|}
\hline \multirow{2}{*}{ Drug } & $\begin{array}{c}\text { Retention time } \\
\text { (Minute) }\end{array}$ & $\begin{array}{c}\text { Retention time } \\
\text { (Minute) }\end{array}$ \\
& Individual Standard & $\begin{array}{c}\text { Composite } \\
\text { Sample }\end{array}$ \\
\hline Metformin $\mathrm{HCl}$ & $\begin{array}{c}\text { Methanol }-6.87 \\
\text { Dimethylacetamide }- \\
20.09\end{array}$ & $\begin{array}{c}\text { Methanol }-6.87 \\
\text { Dimethylacetamid } \\
\text { e-20.09 }\end{array}$ \\
& Benzene -8.60 & Benzene -8.59 \\
\hline Hydrochlorothiazide & $\begin{array}{c}\text { Methanol }-4.99 \\
\text { Methyl isobutyl } \\
\text { ketone }-15.70\end{array}$ & $\begin{array}{c}\text { Methanol }-5.00 \\
\text { Methyl isobutyl } \\
\text { ketone }-15.69\end{array}$ \\
\hline
\end{tabular}

TABLE 3: PARAMETERS OF LINEAR REGRESSIONS OF RESIDUAL SOLVENTS.

\begin{tabular}{|c|c|c|c|c|c|}
\hline Parameters & $\begin{array}{c}\text { Benzene- } \\
\text { MH }\end{array}$ & $\begin{array}{c}\text { DMA- } \\
\text { MH }\end{array}$ & $\begin{array}{c}\text { Methanol } \\
\text {-MH }\end{array}$ & $\begin{array}{c}\text { MIBK- } \\
\text { HCTZ }\end{array}$ & $\begin{array}{c}\text { Methanol } \\
\text {-HCTZ }\end{array}$ \\
\hline $\begin{array}{c}\text { Linearity } \\
\text { Range } \\
(\mathrm{ppm})\end{array}$ & $0.3-1.5$ & $40-250$ & $50-500$ & $80-950$ & $50-500$ \\
\hline Slope & 1665.7 & 10.9 & 124.0 & 1144.6 & 100.2 \\
\hline $\begin{array}{c}\text { Intercept } \\
\text { Correlation } \\
\text { coefficient } \\
\left(\mathrm{r}^{2}\right)\end{array}$ & -4.5 & 6.1 & 326.9 & 32.3 & 332.1 \\
\hline \begin{tabular}{c} 
LOD (ppm) \\
\hline \begin{tabular}{c} 
LOQ (ppm) \\
\hline
\end{tabular}
\end{tabular} & 0.18 & 17.00 & 10.93 & 1.30 & 3.40 \\
\hline
\end{tabular}

TABLE 4: INSTRUMENT PRECISION OF THE PROPOSED METHOD FOR THE DETERMINATION OF RESIDUAL SOLVENT.

\begin{tabular}{|c|c|c|c|c|}
\hline Parameters & $\begin{array}{c}\text { Peak } \\
\text { area of } \\
\text { benzene }\end{array}$ & $\begin{array}{c}\text { Peak } \\
\text { area of } \\
\text { DMA }\end{array}$ & $\begin{array}{c}\text { Peak } \\
\text { area of } \\
\text { methanol }\end{array}$ & $\begin{array}{c}\text { Peak area } \\
\text { of MIBK }\end{array}$ \\
\hline Mean & 2471.67 & 2758.17 & 63660.67 & 109442.50 \\
\hline SD & 49.09 & 51.51 & 658.38 & 832.15 \\
\hline \% RD & 1.99 & 1.87 & 1.03 & 0.76 \\
\hline
\end{tabular}

TABLE 5: ACCURACY RESULTS OF RESIDUAL SOLVENTS FOR BENZENE, DMA, METHANOL AND MIBK.

\begin{tabular}{|c|c|c|c|c|}
\hline Solvent & $\begin{array}{c}\text { Concentration } \\
(\mathbf{p p m})\end{array}$ & $\begin{array}{c}\text { Avg. } \\
\text { peak } \\
\text { area }\end{array}$ & $\begin{array}{c}\text { Concentration } \\
\text { by graph }\end{array}$ & $\begin{array}{c}\% \\
\text { Recovery }\end{array}$ \\
\hline Benzene & 1.80 & 2472.50 & 1.49 & 99.33 \\
\hline DMA & 250 & 2742.8 & 252.09 & 100.84 \\
\hline Methanol & 500 & 63101 & 506.20 & 101.24 \\
\hline MIBK & 950 & 1100225 & 961.20 & 101.18 \\
\hline
\end{tabular}

TABLE 6: ROBUSTNESS OF THE PROPOSED METHOD.

\begin{tabular}{|c|c|c|c|c|}
\hline Condition & $\begin{array}{c}\text { Avg. } \\
\text { peak } \\
\text { area } \\
\text { Benzene } \\
\end{array}$ & $\begin{array}{l}\text { Avg. } \\
\text { peak } \\
\text { area } \\
\text { DMA }\end{array}$ & $\begin{array}{c}\text { Avg. } \\
\text { peak area } \\
\text { methanol }\end{array}$ & $\begin{array}{c}\text { Avg. } \\
\text { peak } \\
\text { area } \\
\text { MIBK }\end{array}$ \\
\hline \multirow{2}{*}{$\begin{array}{c}\text { Oven } \\
\text { temperature } \\
\text { decrease } 5^{\circ}\end{array}$} & 2534 & 2842 & 63395 & 1117007 \\
\hline & $\begin{array}{c}\% \text { RSD }= \\
1.92\end{array}$ & $\begin{array}{c}\% \mathrm{RSD}= \\
2.71\end{array}$ & $\begin{array}{c}\% \text { RSD }= \\
1.44\end{array}$ & $\begin{array}{c}\% \text { RSD }= \\
1.91\end{array}$ \\
\hline \multirow{2}{*}{$\begin{array}{l}\text { Oven } \\
\text { temperature } \\
\text { increase } 5^{\circ}\end{array}$} & 2649 & 2768 & 64580 & 1151902 \\
\hline & $\begin{array}{l}\% \text { RSD } \\
=2.93\end{array}$ & $\begin{array}{c}\% \mathrm{RSD} \\
2.45\end{array}$ & $\begin{array}{c}\% \mathrm{RSD} \\
1.52\end{array}=$ & $\begin{array}{l}\% \text { RSD } \\
=1.51\end{array}$ \\
\hline
\end{tabular}

\section{CONCLUSION}

The proposed investigation was done for the determination of residual solvents in MH and HCTZ using headspace gas chromatography equipped with flame ionization detector. The repeatability and accuracy results of the method were quite satisfactory, and the obtained \%RSD is within the limit of ICH guidelines. This method is sensitive for the quantification of residual solvents present in bulk and dosage forms. We recommend that the proposed method can be applied for routine analysis in academic institutions and research laboratories for its simplicity and low cost.

\section{REFERENCES}

[1] The Indian Pharmacopoeia, 4th ed. Vol.I, New Delhi: The controller of publications, $\mathrm{p}$. 469, 1996.

[2] Budavari S., The Merck index.13th edition, Whitehouse Station Merck \& Co. Inc, p. 998, 2001.

[3] British Pharmacopoeia, Vol. I, The Stationery Office, London, UK, 2007.

[4] ICH guidelines for residual solvents Q3 Step 4, 1997.

[5] Siddiqui M.R., Singh R., Bhatnagar A., Kumar J. and Chaudhary M., "Determination of residual solvents in docetaxel by headspace gas chromatography", Arabian Journal of Chemistry (AJC), Vol. 10 (supplement 2), S2479-S2484, 2017.

[6] Hussain S., Gosar A. and Shaikh, T.,"Determination of residual solvents in neostigmine methyl sulfate by headspace gas 
chromatography"; International Journal of Advanced Research (IJAR), 5(3), p. 17261733, 2017.

[7] Feng X.Z., Han G.C., Qin J., Yin S.and Chen Z., "Determination of residual solvents in linezolid by static headspace GC", Journal Chromatographic Science (CHROMSCI), 54(4): p. 487-491, 2016.

[8] Rahman H., Ratemi E., Haque S.M., and Shanker P., "Development and validation of an analytical method for the determination of residual solvents in oxacillin sodium by headspace gas chromatography",European Journal of Pharmaceutical and Medical Research (EJPMR), 3(10), p. 61-66, 2016.

[9] Haque S.M., "Development and validation for the determination of residual solvents of pharmaceutical formulations of flucloxacillin sodium using headspace gas chromatography", African Journal of Pharmacy and Pharmacology (AJPP), 8(42), p. 1086-1092, 2014.

[10] Pandey S., Pandey P., Kumar R. and Singh N.P., "Residual solvent determination by headspace gas chromatography with flame ionization detector in omeprazole API" Brazilian Journal of Pharmaceutical Sciences (BJPS), 47 (2), p. 379-384, 2011.

[11] Gujral R.S., Haque S.M. and Shanker, P., "A sensitive headspace gas chromatographic method for the determination of residual solvents of cloxacillin sodium and dicloxacillin sodium", American Journal of Scientificand Industrial Research (AJSIR), 1(2), p. 271-278, 2010. 
Yanbu Journal of Engineering and Science Vol. 16 (2018) 
